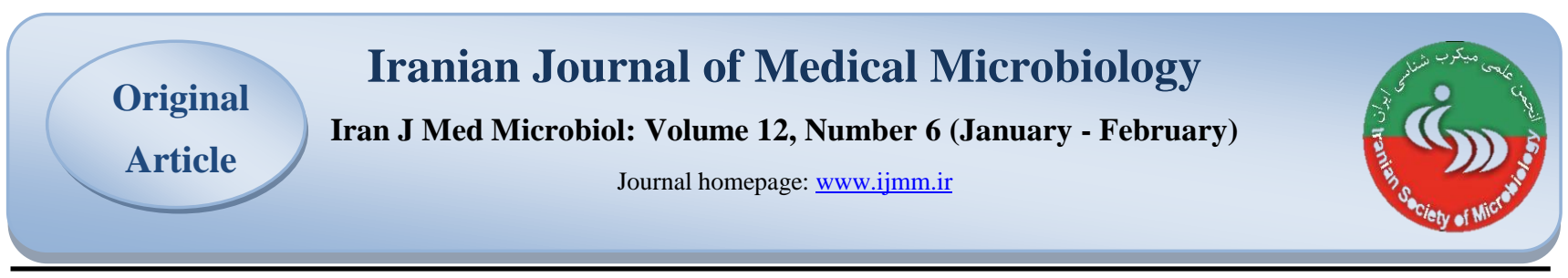

\title{
Detection of Viable But Non-Culturable State of Escherichia coli 0157:H7 Using Reverse Transcription PCR
}

\author{
Mohammad Khezri $^{1}$, Masoud Rezaei ${ }^{*}$, Ashraf Mohabbati Mobarez ${ }^{2}$, Mehdi Zolfaghari $^{3}$ \\ 1. Department of Seafood Science, Faculty of Marine Sciences, Tarbiat Modares University, Noor, Iran \\ 2. Department of Medical Bacteriology, Faculty of Medical, Tarbiat Modares University, Tehran, Iran \\ 3. Department of Seafood Processing, Faculty of Fisheries and Environmental Sciences, Agricultur and Natural Resource University \\ of Gorgan, Gorgan, Iran
}

\section{Article Information}

\section{Article history:}

Received: 2018/11/15

Accepted: 2019/01/22

Available online: 2019/03/06

\section{Article Subject:}

Molecular Bacteriology

IJMM 2019; 12(6): 390-398

Corresponding author:

\section{Masoud Rezaei}

Department of Seafood Science, Faculty of Marine Sciences, Tarbiat Modares University, Noor, Iran

Email:

reza_ma@modares.ac.ir

Use your device to scan and read the article online

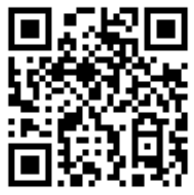

\section{Abstract}

Background and Aims: Many bacteria including Escherichia coli may enter into a viable but non-culturable (VBNC) state under unfavorable stresses, which are unable to be detected by culture-based methods. In this study, the use of Reverse Transcription PCR (RT-PCR) for detection of VBNC state of $E$. coli $\mathrm{O} 157: \mathrm{H} 7$ was investigated.

Materials and Methods: Escherichia coli $\mathrm{O} 157: \mathrm{H} 7$ was inoculated in distilled water and 30 percent salt water at room temperature. The cultivability of bacteria was determined using routine culture and colony counting on MacConkey agar. The RT-PCR of 16S rRNA gene involved direct extraction and purification of RNA, DNase I treatment for removing DNA contamination, cDNA synthesis and electrophoresis of PCR products of cDNA was used to detect viable E. coli $\mathrm{O} 157: \mathrm{H} 7$ under studied treatments and was compared with the results of RT-PCR of 16S rRNA gene of heat- killed bacteria.

Results: The cultivability of bacteria was maintained during the study period in distilled water; however, the use of $30 \% \mathrm{NaCl}$ caused the bacteria to be non-cultivable on day 4 . The RTPCR of 16S rRNA showed the positive expression of this gene in cultivable and non-cultivable bacteria during the study period, whereas heat-killed bacteria were negative for this gene, which indicated the efficacy of RT-PCR of 16S rRNA in differentiation of alive from dead bacteria.

Conclusions: Escherichia coli $\mathrm{O} 157: \mathrm{H} 7$ entered into the VBNC under 30 percent $\mathrm{NaCl}$ which can be associated with serious human health problems. RT-PCR can be used to detect bacteria in the VBNC state.

Keywords: Escherichia coli O157:H7, Bacteria viability, Reverse Transcriptase PCR

How to cite this article:

Khezri M, Rezaei M, Mohabbati Mobarez A, zolfaghari M. Detection of Viable But NonCulturable State of Escherichia coli O157:H7 Using Reverse Transcription PCR. Iran J Med Microbiol. 2019; 12 (6) :390-398 


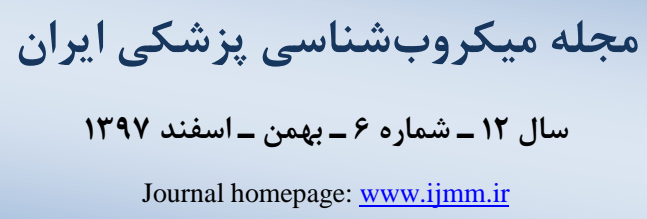

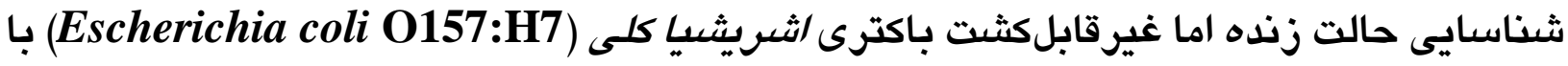 استفاده از وارونويسى واكنش زنجيرهاى يليمراز (RT-PCR)}

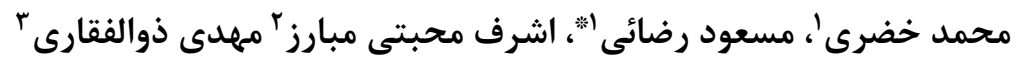

$$
\begin{aligned}
& \text { ا. كروه فرآورى محصولات شيلاتى، دانشكدة علوم دريايى، دانشكاه تربيت مدرس، نور، ايران } \\
& \text { r. كروه باكترىشناسى يزشكى، دانشكدة يزشكى، دانشكاه تربيت مدرس، تهران، ايران }
\end{aligned}
$$

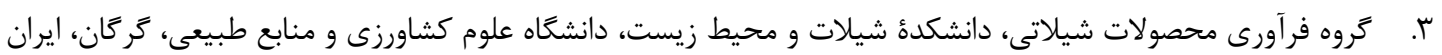

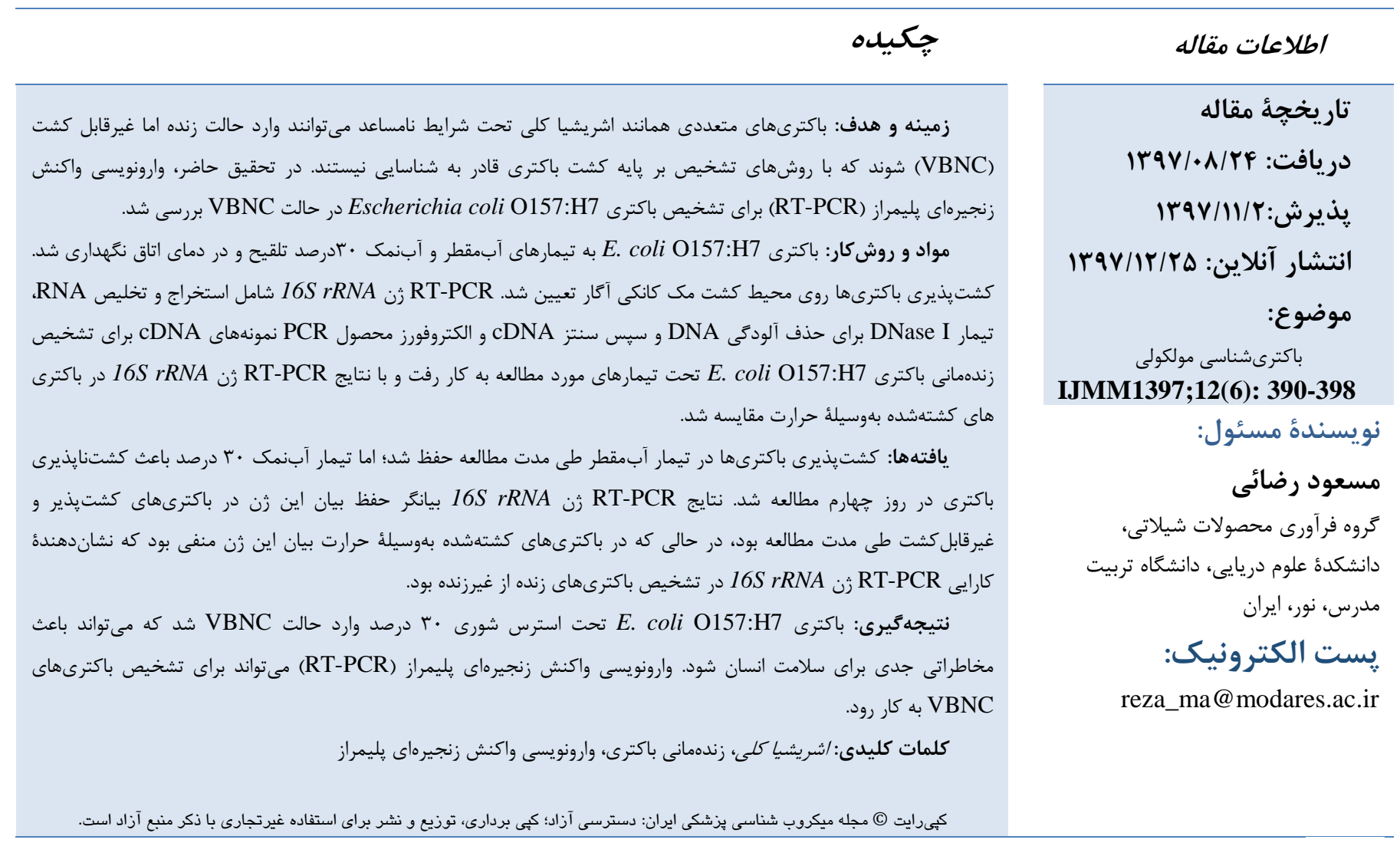

مقام

مدفوعى منابع آبى مختلف و نيز محصولات كشاورزى به اين باكترى باعنوان منابع خطر اين باكترى مطرح هستند (f)، (). باكترى E. coli O157:H7 مىتواند تحت شرايط محيطى مختلف از جمله تغيير دما، pH يايين و ... زنده بماند. همجنين اين

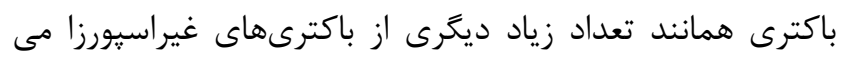

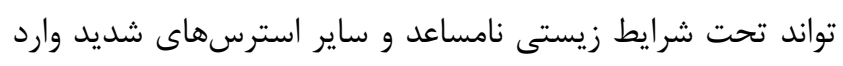

باكترى Escherichia coli O157:H7 يك باكترى بيمارىزاى

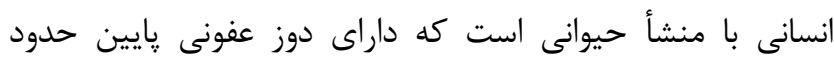

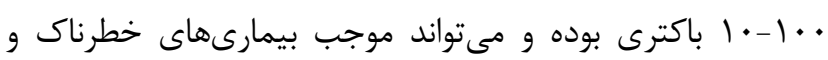
حتى مرى در انسان شود (ب-(). حيوانات اهلى و وحشى از مخازن اصلى باكترى E. coli O157:H7 بهشمار مى آيند. مصرف توشت جرخشده، شير خام و ساير فراوردهاى توليدشده از گاو، آلودگى 
با توجه به نتايج مطالعات انجامگرفته يِيرامون القاى حالت ت تحت شرايط كرسنكى و شورى و

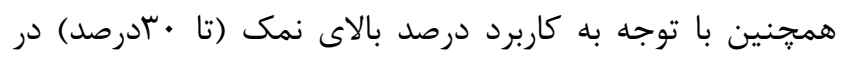

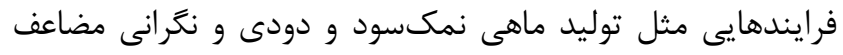
يبرامون القاى حالت VBNC در اين باكترى به ويزه در مورد توليد

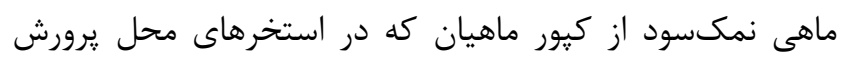

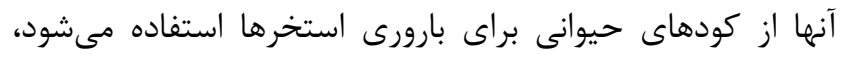

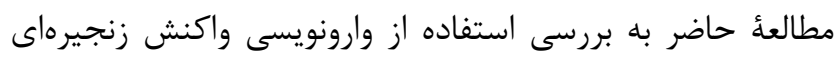

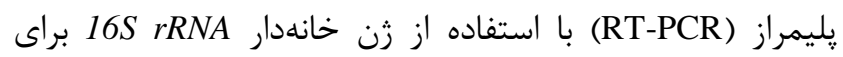

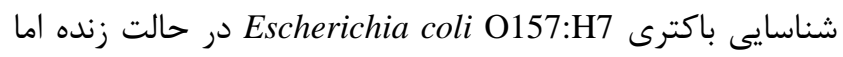
غيرقابل كشت القاشده بهوسيلة استرس شورى اشباع يرداخته شد.

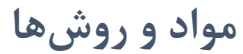

\section{تهيئ سويئ باكترى و آمادهسازى براى تلقيح به تيمارهاى موردمطالعه}

مطالعه حاضر در آزمايشعاههاى فراورى محصولات شيلاتى و

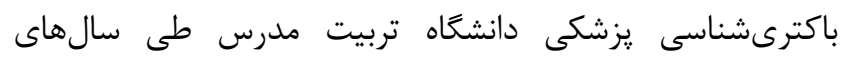

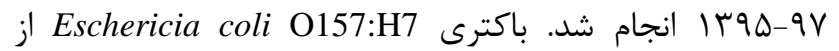
كلكسيون ميكروبى دانشكدة داميزشكى دانشعاه تهران بان به شماره

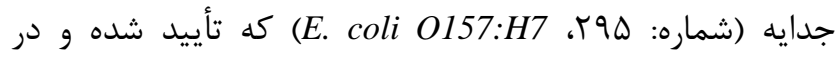
مطالعات مختلفى به كار رفته بود، تهيه شد (با). كلنى خالص و

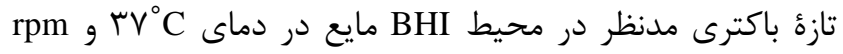

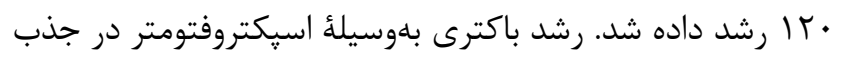

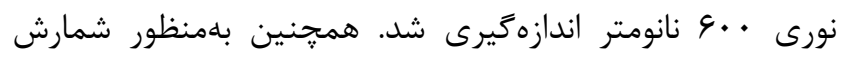

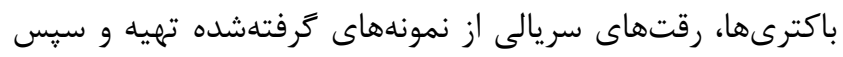

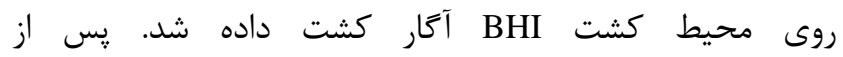

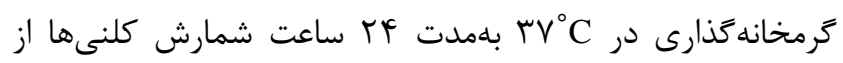

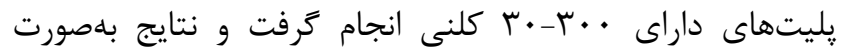
CFU/ml

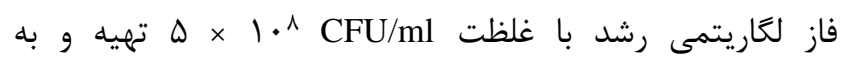

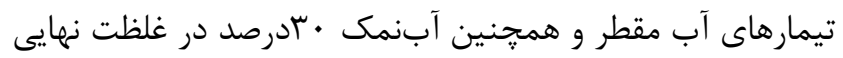
F CFU/ml

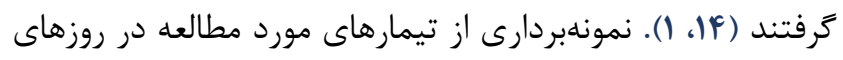

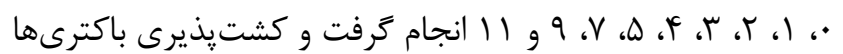

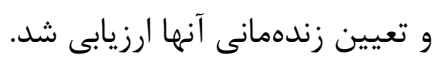

حالت زنده اما غيرقابل كشت (VBNC) شود. حالت VBNC يك

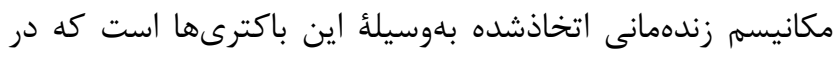

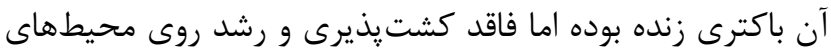

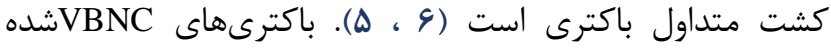

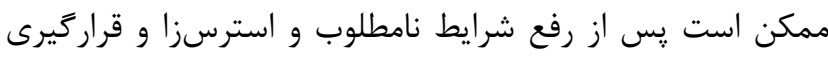
در معرض شرايط مساعد، قابليت رشد و كشت روى محريط محيطهاى كشت را بار ديكر بهدست بياورند و بهاينترتيب مىتوانند موجب مخاطرات جدى شوند (Y-9). در همين رابطه، بيان برخى از

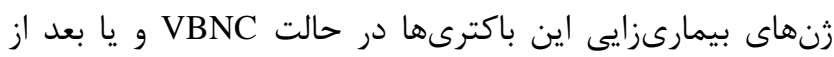

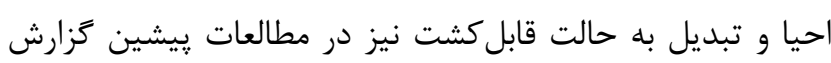

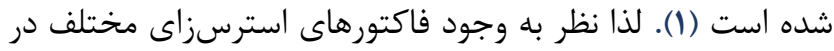

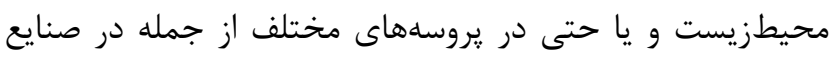

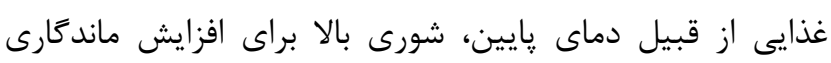

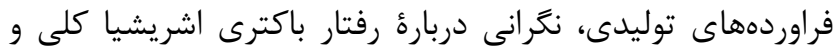

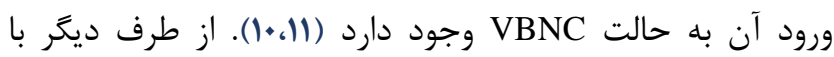

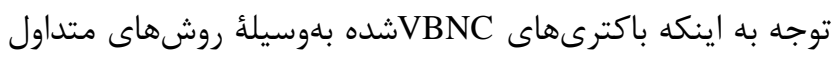
كشت و شمارش كلنى روى محيط كشت قابلشناسايى نبوده و ممكن است كه نمونههاى آزمايششده عارى از إز باكترى قلمداد

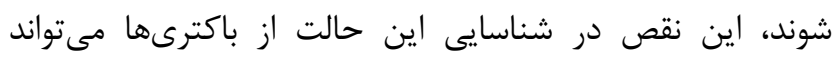

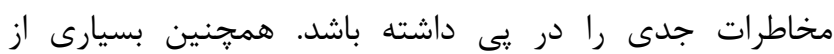
روشاى تشخيصى ديخر از جمله آزمايش ايمنى براساس

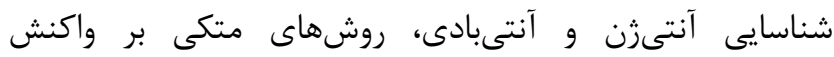

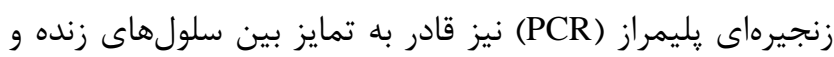

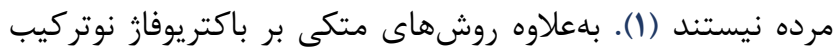

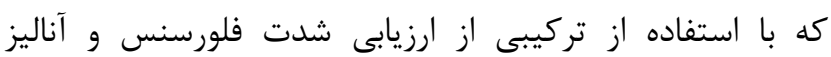

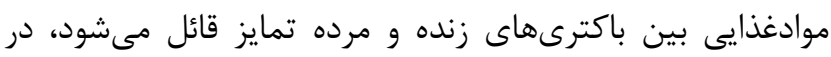
نمونههاى محيطى ناشى از اختلال فلورسنس ناشى ازئ ذاز ذرات

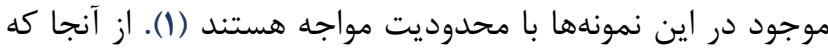

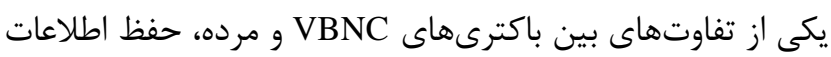

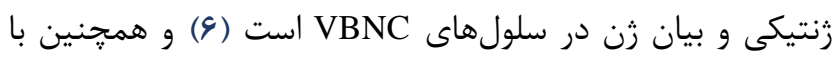
توجه به קِايدارى كوتاهمدت RNA در خارج از سلول زنده، استفاده

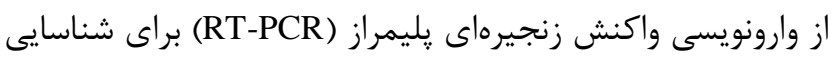
مي RNA زنده مطرح باشد. اين روش شامل استخراج و تخليص RNA، تيمار

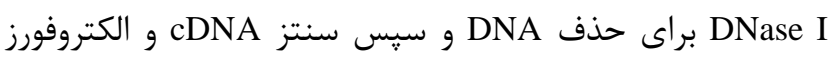

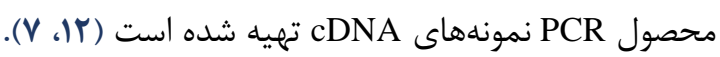




\section{PCR بروسه}

بdمنظور انجام PCR از Prime Taq Premix (2X) (كيازن طب صدرا، ايران) استفاده شد. بهطور خلاصه، • ا ميكروليتر از Prime Taq Premix از مخلوط يرايمرهاى فوروارد و معكوس (هركدام ه ي پيكومولار) مخلوط شده و با آب مقطر ديونيزه استريل به حجم ·r ميكروليتر رسيد. مخلوط فوق براى حذف قطرات روى ديواره ميكروتيوب

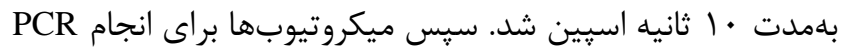

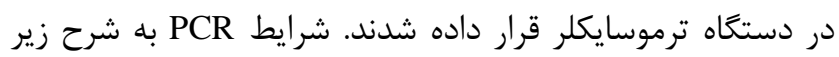

دناتوراسيون اوليه در 9 د $^{\circ} \mathrm{C}$

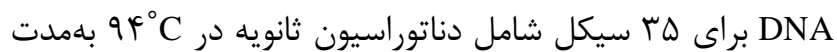

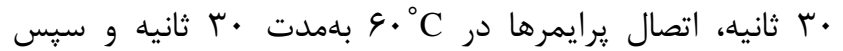

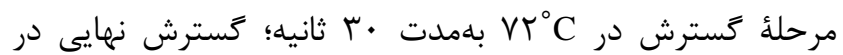

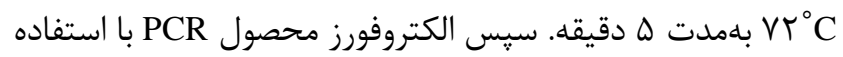

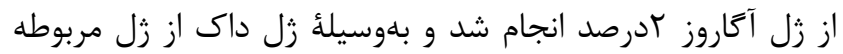
عكس گرفته شد. يرايمرهاى زن 16S rRNA استفادهده در مطالعهُ حاضر، شامل يرايمر فروارد: CAT TGA CGT TAC CCG CAG AA و يرايمر معكوس: CATT ACG CCC AGT AAT TAbp با اندازه محصول نهايى PCR بود (1) برابر TCR

$$
\text { آناليز آمارى }
$$

آزمايشهاى انجامشده در سه تكرار انجام شد. ميانگين و

انحرافمعيار دادهها تعيين شد و براساس آن و با استفاده از إن نرمافزار اكسل نمودارها رسم شدند. نتايج مربوط به بيان زن $16 S$

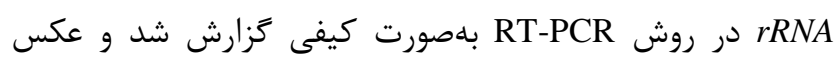
الكتروفورز محصول PCR روى زل آكارز זدرصد ارائه شد.

\section{بافتهها}

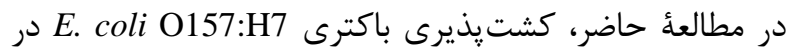

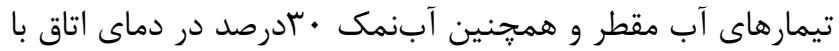
استفاده از روش كشت متداول باكترى و شمارش كلنى مطالعه شد. نتايج نشان داد كه كشتيذيرى باكترىها در تيمار آب مقطر

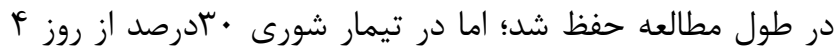

به بعد اين باكترىها فاقد كشتيذيرى بودند (شكل ا و ؟). همجنين در مطالعهُ حاضر RT-PCR زن تشخيص حضور باكترىهاى زنده اما غيرقابل كشت در تيمارهاى آبمقطر و همجنين شورى ·لادرصد انجام شد. همجنين RT-

\section{كشت يذيرى باكترى}

بdمنظور بررسى كشتيذيرى باكترى در تيمارهاى مطالعهشده، در روزهاى مختلف نمونهبردارى صورت گرفت و رقتهاى متوالى از نمونههاى باكتريايى تهيه شد؛ سيس روى روى محيط كشت مك كانكى آكار كشت داده شدند. يس از از كرمخانه كذارى نمونهها، كلنىهاى رشديافته شمارش و بلهصورت CFU/ml كزارش شدند. بهمنظور تعيين وضعيت باكترىهاى كشت ريذير در

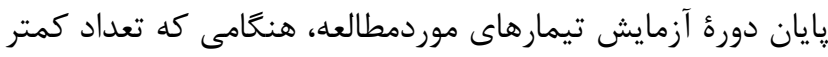

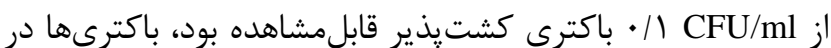
حالت VBNC در نظر گرفته شدند (1).

\section{شناسايى باكترىهاى VBNC بdوسيلئ RT-PCR زن}

16S rRNA

بلمنظور شناسايى باكترىهاى VBNC تحت تيمارهاى موردمطالعه از RT-PCR زن

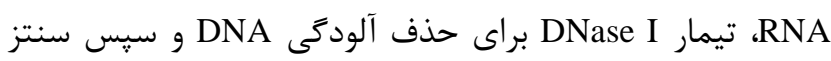
cDNA

ستفاده شد (ه). (1) - (1).

همجنين بامنظور اطمينان از كارايى RT-PCR زن $16 S$ rRNA

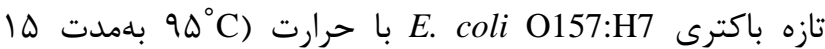
دقيقه) كشته شد. براى باكترىهاى كشتهشده نيز RT-PCR

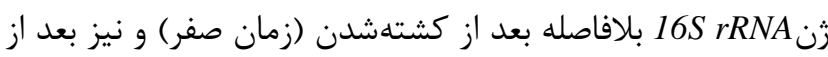

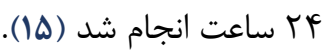

\section{استخراج RNA}

در روزهاى نمونهبردارى، از هر تيمار • ا ميلىليتر از نمونه

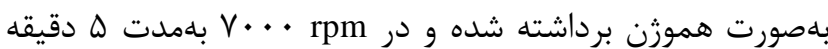
سانتريفيوز شد. رسوب باكترى بهمنظور استخراج RNA تحت ليز سلولى قرار گرفت. بهمنظور استخراج RNA نمونههاى باكترى،

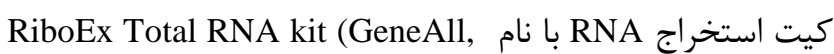
South Korea) كيت DNase I (سيناكلون، ايران) جهت حذف آلودگى DNA استفاده شد. سيس RNA حاصل براى سنتز cDNA با استفاده از كيت Viva 2-step RT-PCR kit (Vivantis, Malaysia) به كار 
• بادرصد و نيز كارايى RT-PCR زن $16 S$ rRNA در تشخيص

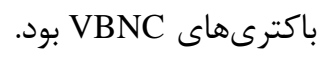

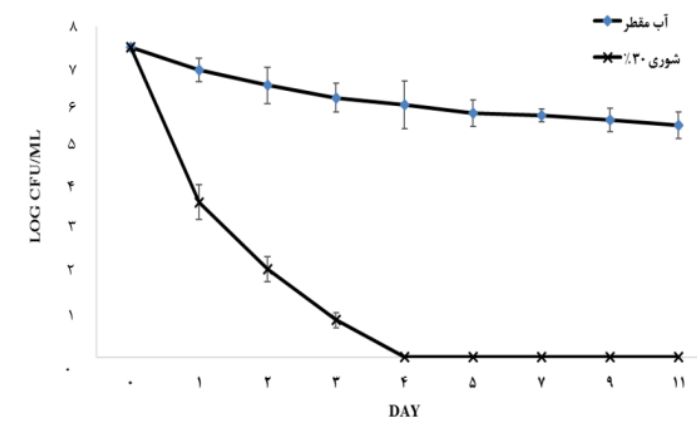

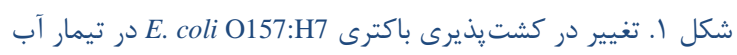
مقطر و همجنين شورى • الدرصد در دماى اتاق
PCR رن 16S rRNA در تيمارهاى فاقد كشتيذيرى باكترى با

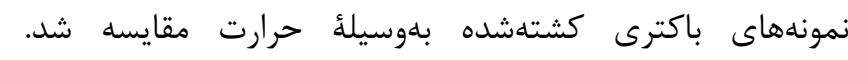

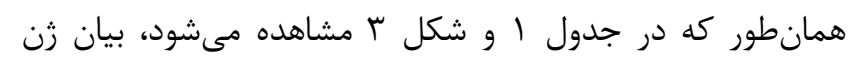

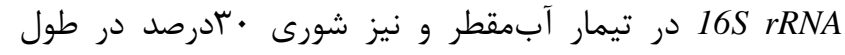

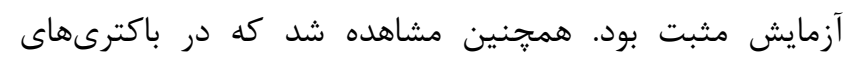

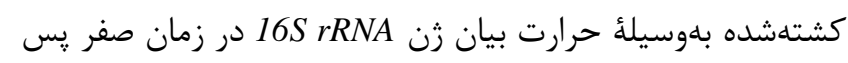

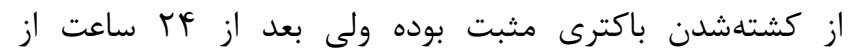

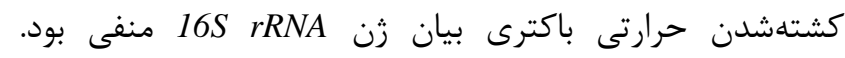

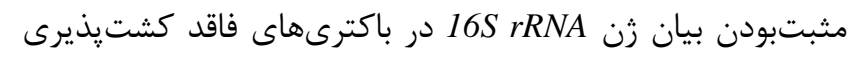

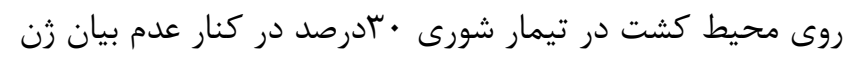
16S rRNA

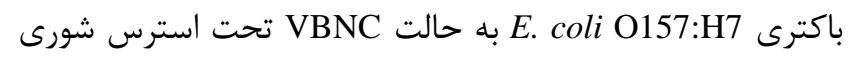

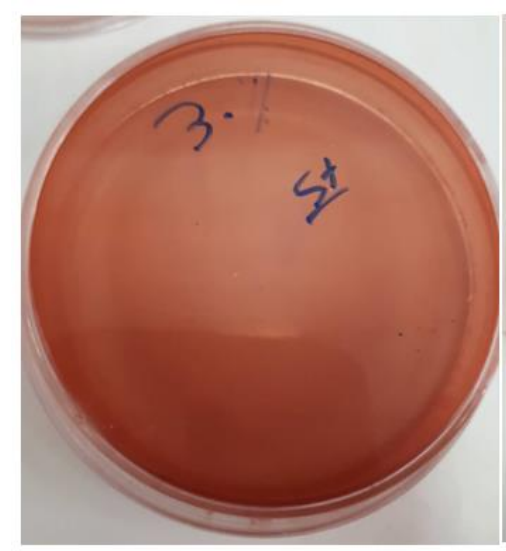

$\varphi$

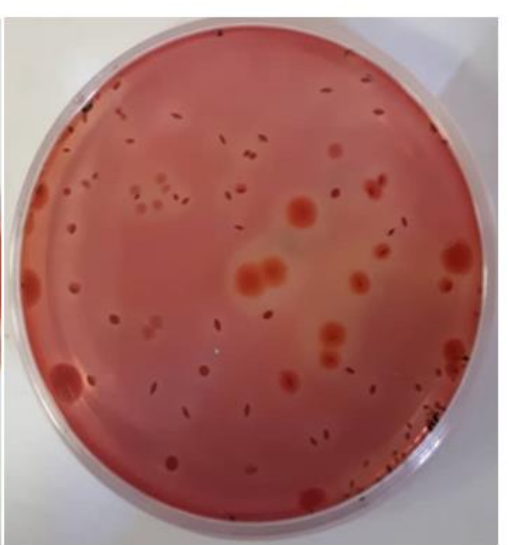

الف - n - n

شكل r. حفظ كشتيذيرى باكترى E. coli O157:H7 در تيمار آب مقطر (الف) و عدم كشتيذيرى تحت شورى • "ادرصد (ب) در دماى اتاق

جدول ا. بيان زن 16S rRNA در باكترى E. coli O157:H7 بهوسيلة RT-PCR در تيمارهاى موردمطالعه

\begin{tabular}{|c|c|c|c|}
\hline 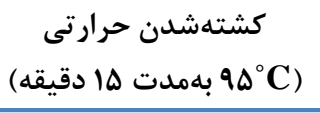 & شورى · بدرصد & آب مقطر & تيمار \\
\hline+ & + & + & • \\
\hline- & + & + & 1 \\
\hline- & + & + & $r$ \\
\hline- & + & + & $r$ \\
\hline- & + & + & f \\
\hline- & + & + & $\Delta$ \\
\hline- & + & + & v \\
\hline- & + & + & 9 \\
\hline- & + & + & 11 \\
\hline
\end{tabular}

+ نشاندهندة بيان مثبت زن 16S rRNA و - نشاندهندة عدم بيان زن 16S rRNA در + 
بلهور كلى توانايى هر باكترى بيمارىزا و بهويزه باكترى Eماى ورود به حالت EBNC coli O157:H7 جنبههاى بهداشت و امنيت موادغذايى اهميت بسيار داشته باشد؛ زيرا باكترىهاى VBNC ممكن است به داخل آب و يا غذا انتقال

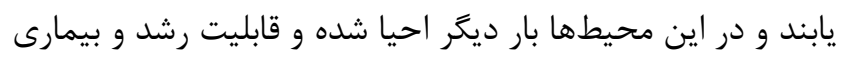

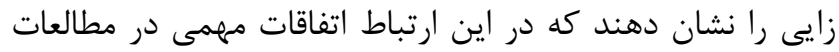

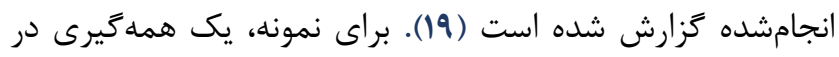

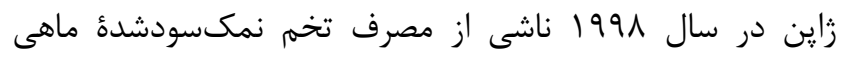

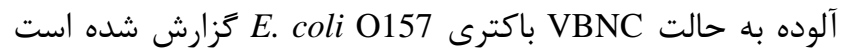

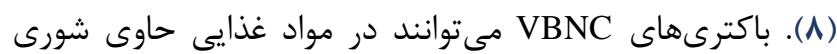

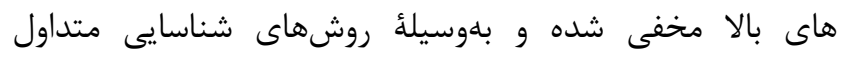
باكترىشناسى شناسايى نشوند. در همين ارتباط Kim و همكاران

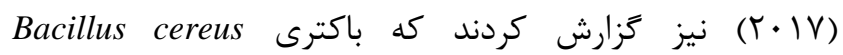
كشتيذيرى خود را در ميكوى نمكسود و تخميرشده، تحت

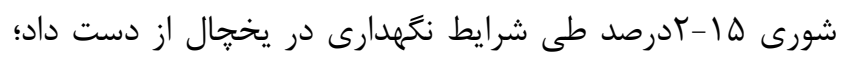
هرجند تحقيقات بيشترى پيرامون زندهمانى اين باكترىها

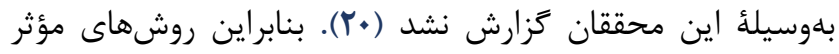

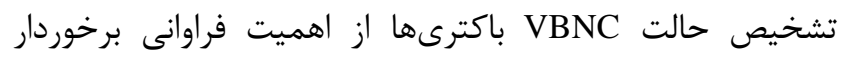
است. همانطور كه مشاهده شد، روشهاى متداول شناسايى باكترىها از جمله كشت مستقيم روى محيط كشت و شمارش

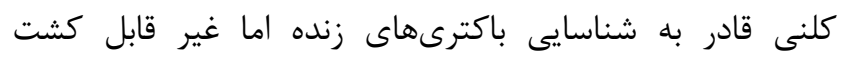

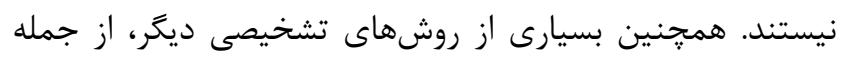

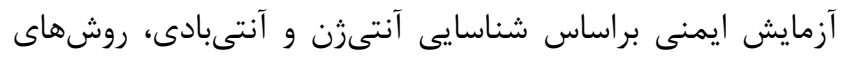

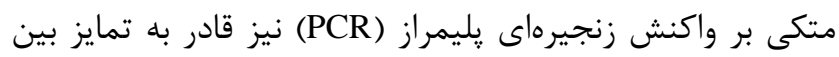

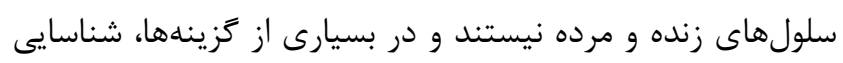
باكترى در نمونههاى محيطى و غذايى با محدوديت مضاعفى

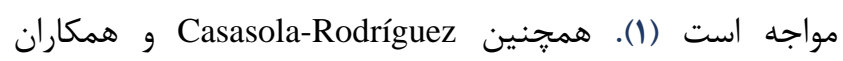

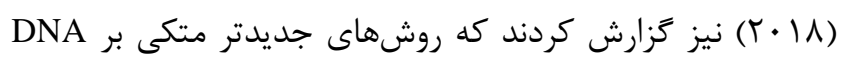
از جمله qPCR-PMA از دقت كافى براى شناسايى باكترىهاى بBNC

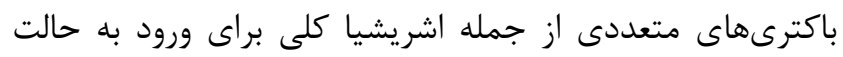

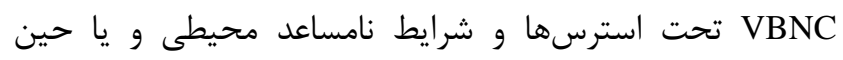
فرايندهاى اعمالشده مثل تيمارهاى ضدعفونى و يا فرايندهاى

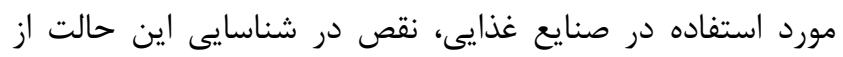

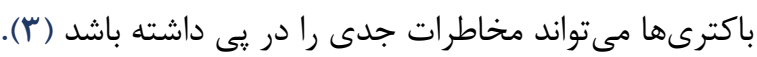
شناسايى موفقيتآميز باكترىهاى زنده اما غير قابل كشت 16S rRNA بهوسيلة RT-PCR coli O157:H7

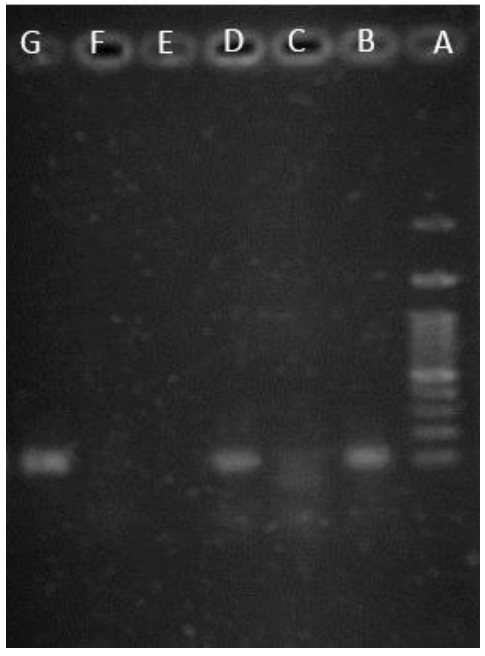

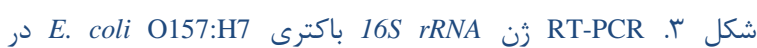

حالتهاى كشتيذير، عدم كشتيذيرى و كشتهشه بلوسيلة حرارت

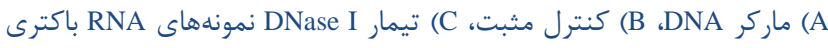

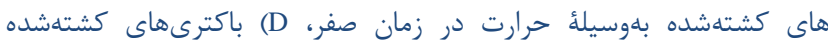

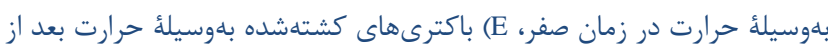

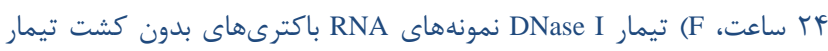

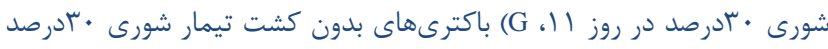

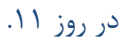

$$
\text { بحث و نتيجهن }
$$

در مطالعه حاضر، باكترىهاى E. coli O157:H7 تحت

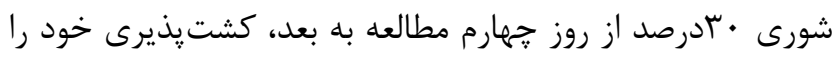

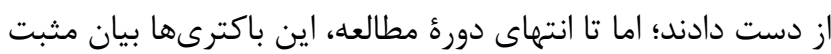

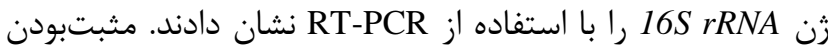

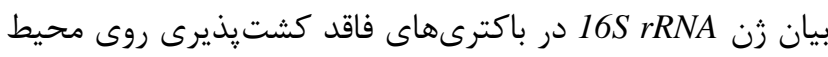

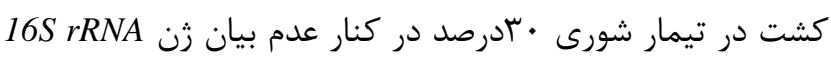
در باكترىهاى كشتهشده بلوسيلة حرارت، بيانكَر ورود اين باكترى

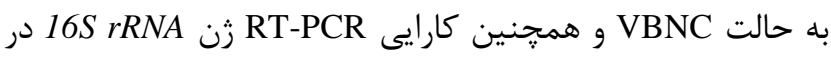

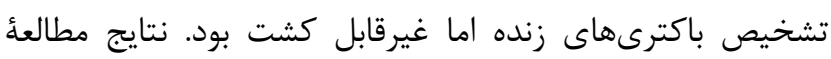

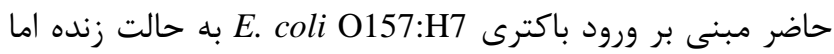
غيرقابلكشت تحت استرس شورى با نتايج مطالعات ييشين

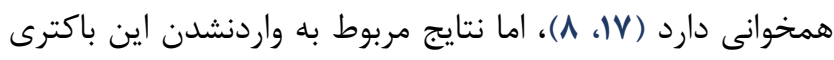
به حالت VBNC در تيمار گرسنكى (آب مقطر) با ساير مطالعات

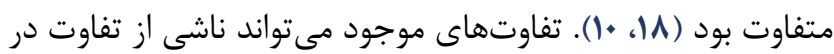
سويههاى باكتريايى مورد مطالعه، شرايط زيستمحيطى مطالعاله،

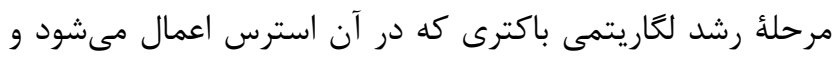
نيز دماى شستشوى باكترى باشد (1)). 
E. coli در جمعبندى مطالعهُ حاضر مىتوان كفت، باكترى

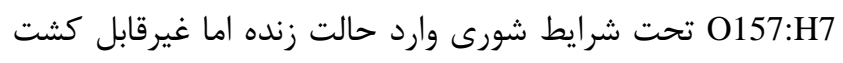
شد و RT-PCR زن 165 rRNA بلبطور موفقيت آميزى توانست اكترىهاى زنده اما غير قابل كشت

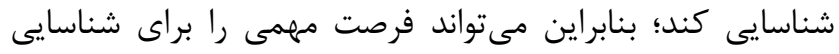

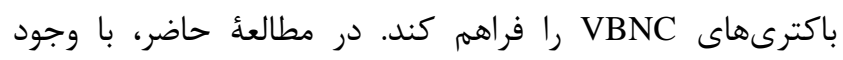
كارايى RT-PCR زن نتايج مثبت كاذب در زمان صفر بعد از كشتهشدن حرارتى باكترى

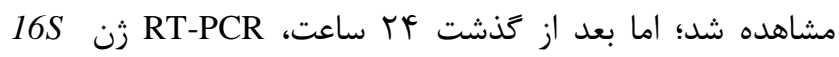
rRNA براى باكترىهاى مرده منفى بود. درنتيجه مىتوان كفت كه

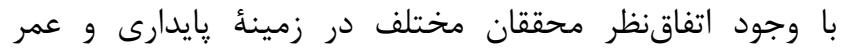

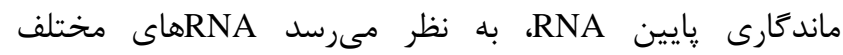

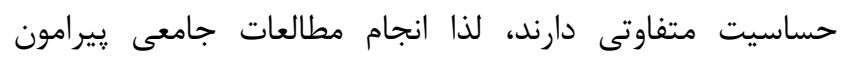
يايدارى و تعيين زمان دقيق ماندكارى RNAهاى مختلف تحت

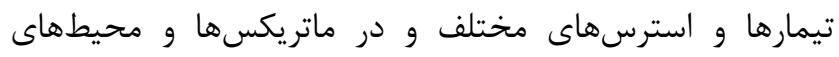

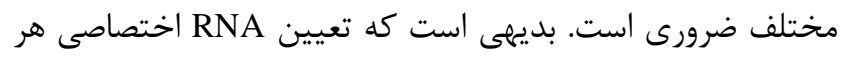

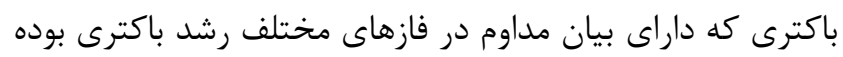
ولى در باكترى مرده بيشترين حساسيت و كمترين زمان بايدارى

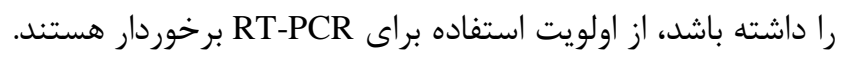

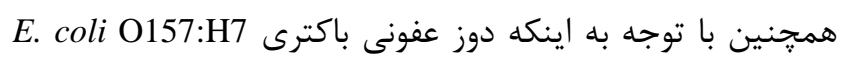
پايين و حدود • إ سلول است، دقت تشخيص متناسب با اين دوز

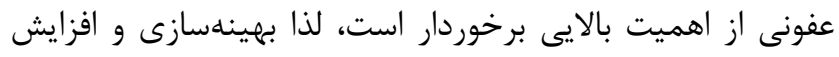

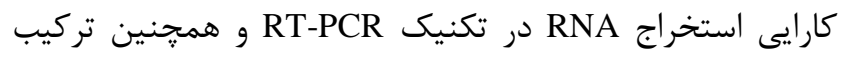

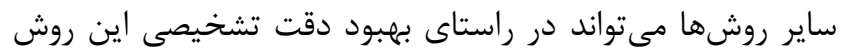
مفيد باشد. همجنين كارايى اين روشها در شناسايى اين حالت از باكترى در نمونههاى محيطى و نمونهاى موائ موادغذايى بايستى

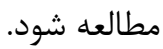

$$
\text { سياسگزارى }
$$

نويسندكان اين مطالعه، مراتب تشكر خود را از صندوق

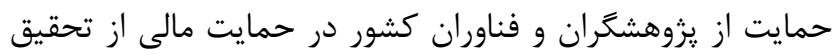

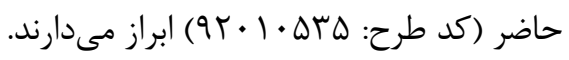

$$
\text { تعارض منافع }
$$

بين نويسندًان تعارض در منافع گزارش نشده است.
حاضر با نتايج مطالعات يِيشين همخوانى دارد. Molaee و همكاران زندة موجود در E. coli زليز

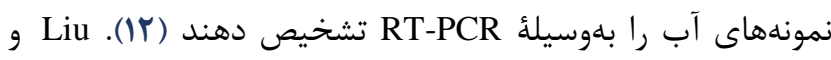

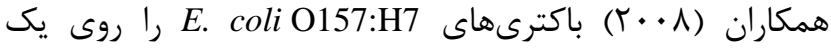

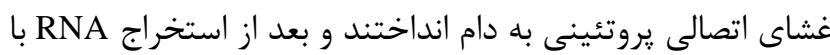
استفاده از RT-PCR و تشخيص ميكروارى زنهاى rfbe و و fliC اين باكترى، توانستند باكترىهاى زنده اما غير قابل كشت را با باليا دقت CFU/ml ا شناسايى كنند (1). در اين راستا مطالعه بيان

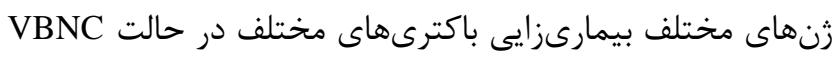

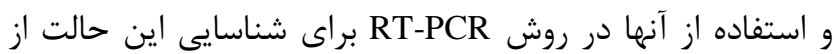

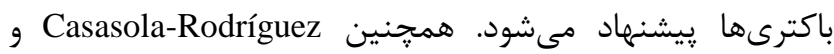

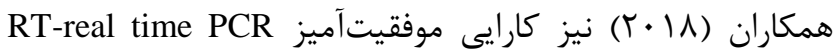

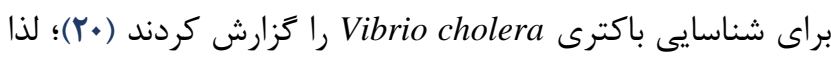
ي يشنههاد مىشود كه كارايى روش RT-PCR رنهاي

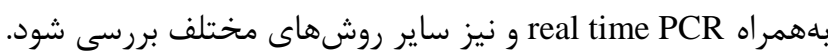
Mar Lleo باكترى Enterococcus faecalis براى شناسايى اين باكترىها در حالت VBNC استفاده كردند (Yr). در مطالعات فوق، همانند

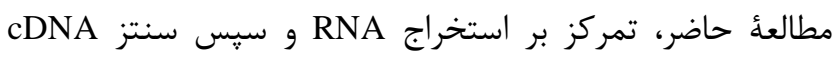
بهمنظور حذف اثرات كاذب DNA مربوط به باكترىهاى مرده بوده است. همجنين عدم بيان زن

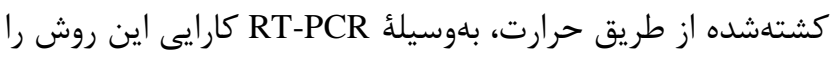
براى تمايز باكترىهاى زنده از غيرزنده نشان مىدهد. همراستا با باريا

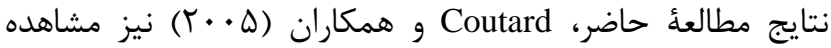
كردند كه كاهش زندهمانى باكترىهاى موردمطالعة آنها ( Vibrio (parahaemolyticus

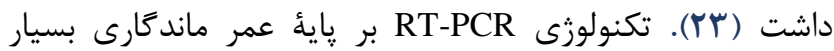

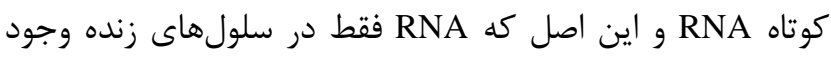

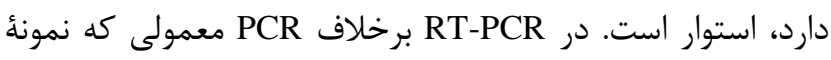

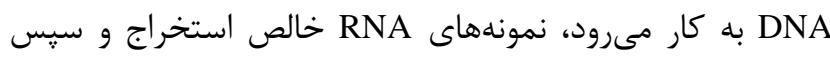
cDNA ساخته شده و در فرايند PCR استفاده مىشود؛ لذا جوابهاى مثبت كاذب ناشى از DNA مربوط به باكترىهاى مرده

حذف مىشود ( آ). 


\section{References}

1. Liu Y, Gilchrist A, Zhang J, Li XF. Detection of viable but nonculturable Escherichia coli O157: H7 bacteria in drinking water and river water. Appl Environ Microbiol. 2008; 74(5): 1502-7. https://doi.org/10.1128/AEM.02125-07

2. McIngvale SC, Chen XQ, McKillip JL, Drake MA. Survival of Escherichia coli O157: H7 in buttermilk as affected by contamination point and storage temperature. J Food Prot. 2000; 63(4): 441-4. https://doi.org/10.4315/0362-028X-63.4.441

3. Yaron S, Matthews KR. A reverse transcriptase-polymerase chain reaction assay for detection of viable Escherichia coli O157: H7: investigation of specific target genes. J Appl Microbiol. $\quad 2002 ; \quad$ 92(4): https://doi.org/10.1046/j.1365-2672.2002.01563.x

4. Kargar M, Homayoon M. Prevalence of shiga toxins (stx1, stx2), eaeA and hly genes of Escherichia coli O157: H7 strains among children with acute gastroenteritis in southern of Iran. Asian Pac J Trop Med. 2015; 8(1): 24-8. https://doi.org/10.1016/S1995-7645(14)60182-6

5. Oliver JD. The viable but nonculturable state in bacteria. The journal of microbiology. 2005; 43(1): 93100 .

6. Oliver JD. Recent findings on the viable but nonculturable state in pathogenic bacteria. FEMS Microbiol Rev. 2010; 34(4): 415-25. https://doi.org/10.1111/j.1574-6976.2009.00200.x

7. Li L, Mendis N, Trigui H, Oliver JD, Faucher SP. The importance of the viable but non-culturable state in human bacterial pathogens. Front Microbiol. 2014; 5: 258. https://doi.org/10.3389/fmicb.2014.00258

8. Makino SI, Kii T, Asakura H, Shirahata T, Ikeda T, Takeshi K, et al. Does Enterohemorrhagic Escherichia coli O157: H7 Enter the Viable but Nonculturable State in Salted Salmon Roe?. Appl Environ Microbiol. 2000; 66(12):

$5536-9$ https://doi.org/10.1128/AEM.66.12.5536-5539.2000

9.Zhao X, Zhong J, Wei C, Lin CW, Ding T. Current perspectives on viable but non-culturable state in foodborne pathogens. Front Microbiol. 2017; 8: 580. https://doi.org/10.3389/fmicb.2017.00580

10. Ding T, Suo Y, Xiang Q, Zhao X, Chen S, Ye X, et al. Significance of viable but nonculturable Escherichia coli: induction, detection, and control. J Microbiol Biotechnol. 2017; 27(3): 417-28. https://doi.org/10.4014/jmb.1609.09063

11. Ramamurthy T, Ghosh A, Pazhani GP, Shinoda S. Current perspectives on viable but non-culturable (VBNC) pathogenic bacteria. Frontiers in public health. 2014; 2: 103.
12. Molaee N, Abtahi H, Ghannadzadeh MJ, Karimi M, Ghaznavi-Rad E. Application of Reverse Transcriptase-PCR (RT-PCR) for rapid detection of viable Escherichia coli in drinking water samples. J Environ Health Sci Eng. 2015; 13(1): 24.

13. Koochakzadeh A, Askari Badouei M, Zahraei Salehi T, Aghasharif S, Soltani M, Ehsan M. Prevalence of Shiga toxin-producing and enteropathogenic Escherichia coli in wild and pet birds in Iran. Rev Bras Cienc Avic. 2015; 17(4): 445-50.

14. Sue D, Boor KJ, Wiedmann M. $\sigma B$-dependent expression patterns of compatible solute transporter genes opuCA and lmo1421 and the conjugated bile salt hydrolase gene bsh in Listeria monocytogenes. Microbiology. 2003; 149(11): 3247-56.

15. Tan Q, Xu H, Chen T, Li P, Aguilar ZP, Xu D, et al. Differential expression of virulence and stress fitness genes during interaction between Listeria monocytogenes and Bifidobacterium longum. Biosci Biotechnol Biochem. 2012; 76(4): 699-704.

16. Spano G, Beneduce L, Terzi V, Stanca AM, Massa S. Real-time PCR for the detection of Escherichia coli O157: H7 in dairy and cattle wastewater. Lett Appl Microbiol. 2005;40(3):164-71

17. Lothigius Å, Sjöling ̊̊, Svennerholm AM, Bölin I. Survival and gene expression of enterotoxigenic Escherichia coli during long-term incubation in sea water and freshwater. J Appl Microbiol. 2010; 108(4): 1441-9. https://doi.org/10.1111/j.1365-2672.2009.04548.x

18. Dinu LD, Bach S. Induction of viable but nonculturable Escherichia coli O157: H7 on the phyllosphere of lettuce: a food safety risk factor. Appl Environ Microbiol. 2011; 77(23): 8295-302. https://doi.org/10.1128/AEM.05020-11

19. Trevors JT. Viable but non-culturable (VBNC) bacteria: gene expression in planktonic and biofilm cells. J Microbiol Methods. 2011; 86(2): 266-73. https://doi.org/10.1016/j.mimet.2011.04.018

20. Kim M, Young Park S, Jung Park T, Ha SD. Effect of Sodium Chloride on the Reduction of Bacillus Cereus in Shrimp Jeotgal During Refrigerated Storage. Journal of Food Safety. 2017; 37(1): e12281. https://doi.org/10.1111/jfs.12281

21. Casasola-Rodríguez B, Ruiz-Palacios GM, Pilar RC, Losano L, Ignacio MR, Orta de Velásquez MT. Detection of VBNC Vibrio cholerae by RT-Real Time PCR based on differential gene expression analysis. FEMS Microbiol Lett. 2018; 365(15): fny156. https://doi.org/10.1093/femsle/fny156

22. del Mar Lleò M, Pierobon S, Tafi MC, Signoretto C, Canepari P. mRNA detection by reverse transcriptionPCR for monitoring viability over time in an Enterococcus faecalis viable but nonculturable population maintained in a laboratory microcosm. Appl 
Environ Microbiol. 2000; 66(10): 4564-7. https://doi.org/10.1128/AEM.66.10.4564-4567.2000

23. Coutard F, Pommepuy M, Loaec S, Hervio-Heath D. mRNA detection by reverse transcription-PCR for monitoring viability and potential virulence in a pathogenic strain of Vibrio parahaemolyticus in viable but nonculturable state. J Appl Microbiol. 2005; 98(4): 951-61. https://doi.org/10.1111/j.1365-2672.2005.02534.x 